\title{
Becoming a Yam: Healing Narratives as Political Resistance in the Time of COVID-19
}

\author{
Latoya B. Brooks * and Kareema J. Gray
}

Program School of Social Work, Johnson C. Smith University, Charlotte, NC 28216, USA; kgray@jcsu.edu

* Correspondence: lbrooks2@jcsu.edu

\begin{abstract}
COVID-19 created a crisis that forced people to deal with the social, emotional, personal, and interpersonal impact of the virus in the United States. Simultaneously, Black people continued to be murdered and victimized by systemic racism and social injustice. Choosing wellness, self-recovery, and self-care during the global pandemonium surrounding the COVID-19 pandemic serves as an act of political resistance in the face of oppression and violence. The purpose of this essay is to explore the authors' embodied uses of personal narratives centering the work sisters of the yam: black women and self-recovery, feminist theory, and African-centered social work paradigms as coping strategies and healing work during the COVID-19 pandemic.
\end{abstract}

Keywords: Black women; COVID-19; African-centered healing; feminist theory; narratives

check for updates

Citation: Brooks, Latoya B., and Kareema J. Gray. 2021. Becoming a Yam: Healing Narratives as Political Resistance in the Time of COVID-19. Genealogy 5: 31. https://doi.org/ 10.3390/genealogy5020031

Received: 26 January 2021

Accepted: 22 March 2021

Published: 25 March 2021

Publisher's Note: MDPI stays neutral with regard to jurisdictional claims in published maps and institutional affiliations.

Copyright: (c) 2021 by the authors. Licensee MDPI, Basel, Switzerland. This article is an open access article distributed under the terms and conditions of the Creative Commons Attribution (CC BY) license (https:// creativecommons.org/licenses/by/ $4.0 /)$.

\section{Introduction}

While the world was dealing with a COVID-19 pandemic, the United States also dealt with unrest as weary citizens marched and protested the ongoing murder and brutalization of unarmed Black people by police officers (Tello 2020). Black people continue to be murdered and victimized by systemic racism and social injustice. As Black women, the authors, found that their identities as a friend, family member, social work educators, scholars, and clinicians, were impacted by the abrupt change within the social landscape as most activities were done in physical isolation. The changing demands of the environment lead the authors to explore/reflect on how Black women found healing during uncertain times. The authors connected at the beginning of the quarantine to read and reflect upon sisters of the yam: black women and self-recovery and found its concepts valuable to their coping.

Choosing wellness, joy, and self-care is an act of Black political resistance (Hooks 2015; Packnett 2017; Lu and Steele 2019). Hooks (2015) writes that living in a white-supremacist, capitalistic, patriarchal environment is fertile ground for exploiting the Black experience. We need the firm grounding knowledge of self-identity and awareness of who we are and where we come. Hooks (2015) encourages Black women to engage in the process of self-recovery as a liberatory political practice in order to continue engaging in sustainable, organized, fully functioning liberation work.

As Black women heal our individual wounds, we become more able to engage in collective healing needed for transformational change (Hooks 2015). Greg Carr wrote that a genealogy can serve as reflective of a historical continuum across space and time throughout the African world (as cited in Carroll 2010). Using an African-centered perspective of genealogy it calls for social workers and scholars to explore the continuity and interconnected relationships are important aspects of cultural connections among people of African descent (Carroll 2010). The purpose of this essay is to examine the authors' use of the work sisters of the yam: black women and self-recovery (Hooks 2015), feminist theory, and African-centered paradigms as coping strategies and healing work during the COVID-19 pandemic through the use of narratives. The authors' narratives discuss the 
various concepts for healing that provided the conceptual frameworks for creating mutual aid and building support networks during the pandemic to maintain wellness.

\section{Engaging Community for Self-Recovery}

Hooks $(2015$, p. 6) described the yam as a life-sustaining symbol that connects Black women to the African diaspora. It serves as a symbol that links community and kinship, provides nourishment and healing for the body as a medicinal food. The "yam" is a universal linkage to the authors' experience connecting to self, sisterhood and healing. The feminist theorical framework presented in sisters of the yam implore Black women to counter the stereotypical expressions of white-supremacist, capitalist patriarchy by decolonizing our minds, creating our own reality, and engaging in self-recovery, self-actualization for Black liberation (Hooks 2015).

One of the central themes to African-centered social work paradigms and Black feminist theory is community. Community includes unity, family, promoting the fundamental goodness of people, encouraging individual and collective functioning, understanding the role and significance of spirituality and interdependence, self-determination in defining, naming, and creating for oneself (Gilbert et al. 2009; Bent-Goodley et al. 2017). Malidoma Somé (1997) describes a functioning community as one where formation and cohesion begins in the hearts of the members. Community is a nurturing place where members feel a sense of unity, trust and openness that assumes its members have good intentions (Somé 1997). It offers a sense of love, caring, and sharing, respect for the elders, respect for nature and respect for ancestors. Community offers its members a place for self-definition and connection. Involvement with community allows for participants to engage in exploration of frustrations, restoration of inner power and participation in ritual (Somé 1997). The authors spent time building community during this time the pandemic with intentionality.

Similarly, the authors connected themselves to their individual ancestors, families, community, and personal experiences from reading sisters of the yam: black women and self-recovery as tools to make meaning during these uncertain times. The shared work also connected them to the collective experiences as women of African descent working to make meaning during the pandemic and continuous epidemic of systematic racism, discrimination, and brutality. The authors used narratives combined with theoretical frameworks to embody, engage and build connections with each other, with family, with community, nature, spirituality and to develop healthy coping strategies.

\section{Narratives for Personal Transformation}

The first narrative is provided by the second author sharing her quarantine story. The second narrative is provided by the first author highlighting her experience learning and building community.

\subsection{My Quarantine Narrative: Second Author's Story}

When we were sent home for spring break in March 2020, with no real plan or timeline for how long we would be there, my initial response was nervousness. Then I jumped into immediate action, notifying students about making sure they bring as many school materials home with them as they could because we did not know if or when they would be allowed back on campus. After doing what I could for my students, I checked on the faculty in my department and made sure they had what they needed for this journey into the unknown. Then, I gathered up all that I thought I might need for every situation that I could imagine in my head.

Once I was settled at home, I went into "project mode". The first project was reorganizing my home office to now become my main office. I did not just move furniture around, I bought bookcases, whiteboards, wall calendars, writing supplies, and even a bit of décor. Once that was completed, I looked around and realized one thing that I had not even considered. I was alone, and I would remain alone for the immediate future and beyond. 
All of my physical needs-food, clothing, cleaning supplies, etc. had been addressed. The next hurdle and more importantly, what am I going to do with myself, by myself?

Recognizing that I will need daily human contact, I developed a plan. Calling on my various sister circles-best friends from college, spiritual prayer warriors from church, colleagues from work, my family members, I set up time to intentionally connect with one person from one of my support circles every day. I also knew that I could not be in the house 24 hours a day, seven days a week alone. I scheduled time every day to go outside - not my backyard but away from the house. This could include a walk in the local park or a walk along one of the greenways in Charlotte, or even a bicycle ride (I bought a new bicycle too!). My church pivoted to virtual services and I participated in a Zoom call with my spiritual family group every Sunday after the virtual service ended. This connection with others I knew was essential to maintaining a healthy state of mind amid all this chaos.

Not only do I teach social work, but I am also still a practitioner-medical social work. I picked up more shifts at the local hospital to lend a hand-the need was desperate. I also was called on by my alma maters (high school and undergraduate) to assist them as they reckoned with their own racial histories and tried to forge a new path forward toward creating a more socially and racially just environment for the current students (both are PWIs). I was a keynote speaker for one racial justice summit and a panelist for another. I even participated in a few protests in Charlotte, NC-I felt compelled, had to do something! But what I had to remember was to make time to address my own thoughts, fears, anxieties about the COVID-19 pandemic, the safety of my family in Pennsylvania and Georgia. I had to take the time to meditate, to trust in God and continue to have faith in his timing. I had to remember to make those daily connections that spoke to my soul and healed my heart. I had to remind myself to connect with nature, to stop and bask in the sun, to get to the beach and feel the sand in my toes (while keeping my 6 feet of social distance from others doing the same).

\subsection{Reclamation of Self: First Author's Story}

I was a new faculty member to the school of social work at our institution, and our initial interactions lead to the development of our writing and nurturing circle. Rereading sisters of the yam and working together added to my healing journey during this time. For example, as a social worker, I am trained in western models of therapeutic intervention. In reflecting on creating major shifts and transformation, the most growth that I experienced has been using African-centered paradigms and spirituality to make meaning and connect with myself. The transition from working outside of the home to quarantine indoor caused me anxiety and panic. I had the therapeutic tools to manage my emotions, yet I felt called to connect with Afrocentric practices and modalities of healing. At the beginning of the pandemic I started working with an Iyalorixa (Yoruba Priestess) of Osun to connect with Ifa Orisha spirituality. Our work together emphasized with the importance of family and knowledge of self through ancestor reverence, spirituality and community.

\subsection{Ancestor Reverence}

The first task that my Iyalorixa gave me was to set up my own ancestor altar. Ancestor reverence allowed me to honor and celebrate my deceased family members while seeking connection, guidance, and protection (Teish 1985; Somé 2002). I cleaned and placed a white cloth, pictures, candles, water, rum, food, and mementos of my mother, aunt, uncle, cousin and brother on the altar. Each morning I sat at my altar to pray, sing, chant and meditate. The more that I connected with my ancestors the more I wanted to know about my lineage and where we came from. I signed up for Ancestry.com and created a family tree. I was able to locate my maternal linage back to four generations to my great great great great grandfather born in the 1700s from Bordeaux, Gironde, Aquitaine, France. The family tree exercise allowed me to spend hours talking with my maternal aunt to identify other ancestors and connect with living elders. I was able to find a picture of my great 
grandfather that I added to my altar. The quest to learn about my ancestors filled gaps and answered questions. The experience of being with them each morning has added to sense of self and created a morning ritual that grounds me and guides me on my path each day.

\subsection{Oneness with Spirit and Nature}

My next assignment was to connect with the Divine. Everything spirit, from an Afrocentric spiritual lens, connects to nature and the earth (Mbiti 1989, p. 48). I was assigned to read The Spirit of Intimacy: Ancient Teachings in the Ways of Relationships by Sobonfu Somé and Ritual: Power, Healing, and Community by Malidoma Somé. These readings offered me a fresh perspective to think about spirit, ritual, and community. I was given ritual to observe for Osun, the Yoruba goddess of love, marriage, and fertility. My first ritual was to offer honey and prayers to Osun at a nearby river. During my walks, I would pray at the river. I took my sneakers off and walked in the grass giving words of gratitude to Mother Earth. I found a tree in the park to hug and prayed. At home I planted a garden on the patio of strawberries, aloe, chamomile, lavender, mint, and sage. I took the first harvest from my garden and offered it to the river for Osun as a result I experienced peace and tranquility each day.

Tapping into my spirit learned to be comfortable with stillness, peace and unbusiness. I used my new spiritual practices as rituals for coping, identity mending and functioning. The practices provided me connection to my Higher Self and the Divine, my local community and nature.

\subsection{Redefining Community}

During the last academic year, I had to endure a number of changes regarding community. I began my faculty position at my current institution fall of 2019 and relocated to a new community hour away from campus in South Carolina. The stress of COVID as an unknown sent the nation into quarantine at home for several months. Away from my family in New York and at a new institution in an unfamiliar region, I learned to redefine my community. I expanded my social support and built connections by creating or joining sister circles with groups of women to focus on writing, healing, and comradery. I used Zoom, WhatsApp, and Microsoft Teams to gather with my circles. Being able to "see" my new community virtually helped eliminate some of the stress of not being able to visit in person.

The practice of redefining community led me to collaborate with other faculty at local HBCUs to discuss stress management techniques and coping skills. We discussed African-centered practices explored in sisters of the yam and encouraged other to engage in rest and self-care as we supported students and community projects for social justice.

\section{Conclusions}

Through the lessons learned, the authors found renewal with "the yam" by reimagining community, working with spirit, and connecting with self. The authors recommend utilizing the various concepts mentioned in this essay for personal transformation and as an intervention in social work practice. Reflecting upon conventional wisdom regarding Black women, the myth of the "strong" Black woman has served as a burden to the emotional development and healing of women. The authors call for the readers to shed the dutiful overburdened stereotype. Embracing healing, wellness, and community can provide linkages to practices of our collective ancestors who healed before us. Sharing secrets of healing and using our collective power to the fullest allows for us to know ourselves, experience sustained joy, and engage in political resistance (Hooks 2015).

Author Contributions: Conceptualization, L.B.B. and K.J.G.; investigation, L.B.B. and K.J.G.; resources, L.B.B.; writing-original draft preparation, L.B.B.; writing-review and editing, L.B.B. and K.J.G. All authors have read and agreed to the published version of the manuscript.

Funding: This research received no external funding. 
Institutional Review Board Statement: Not applicable.

Informed Consent Statement: Not applicable.

Data Availability Statement: This study did not report any data.

Acknowledgments: The authors would like to acknowledge our ancestors, our elders, our communities, colleagues in the School of Social work and all of the healing and supportive networks that kept us grounded as we completed this essay.

Conflicts of Interest: The authors declare no conflict of interest.

\section{References}

Bent-Goodley, Tricia, Colita Nichols Fairfax, and Iris Carlton-LaNey. 2017. The significance of African-centered social work for social work practice. Journal of Human Behavior in the Social Environment 27: 1-6. [CrossRef]

Carroll, Karanja Keita. 2010. A Genealogical Review of the Worldview Framework in African-Centered Psychology. The Journal of Pan African Studies 3: 109-34.

Gilbert, Dorie J., Aminifu R. Harvey, and Faye Z. Belgrave. 2009. Advancing the Afrocentric Paradigm Shift Discourse: Building toward Evidence-Based Afrocentric Interventions in Social Work Practice with African Americans. Social Work 54: 243-52. [CrossRef] [PubMed]

Hooks, Bell. 2015. Sisters of the Yam: Black Women and Self-Recovery. New York: Routledge/Taylor \& Francis Group.

Lu, Jessica H., and Catherine Knight Steele. 2019. 'Joy is resistance': Cross-platform resilience and (re)invention of Black oral culture online. Information, Communication \& Society 22: 823-37. [CrossRef]

Mbiti, John S. 1989. African Religions and Philosophy. New Hampshire, USA: Heinemann Educational Publishers.

Packnett, Brittany. 2017. I'm an Activist, and Joy Is My Resistance. Available online: https://www.self.com/story/charlottesville-joyis-resistance (accessed on 21 July 2020).

Somé, Malidoma. 1997. Ritual: Power, Healing, and Community. New York: Penguin Compass.

Somé, Sobonfu. 2002. The Spirit of Intimacy: Ancient Teachings in the Ways of Relationships. New York: HarperCollins Publishings.

Teish, Luisah. 1985. Jambalaya: The Natural Woman's Book. New York: Harper \& Row.

Tello, Monique. 2020. Protesting in the Time of COVID-19; Harvard Health Blog. Available online: https://www.health.harvard.edu/ $\mathrm{blog} /$ protesting-in-the-time-of-covid-19-2020070120541 (accessed on 24 July 2020). 